\title{
Consistency of control of damping-off of cucumber is improved by combining ethanol extract of Serratia marcescens with other biologically based technologies
}

Daniel P. Roberts*, Laurie F. McKenna, and Jeffrey S. Buyer

Sustainable Agricultural Systems Laboratory, USDA-ARS, Beltsville Agricultural Research

Center, Beltsville, MD 20705

"Corresponding author:

Building 001, Rm. 245B, 10300 Baltimore Avenue, Beltsville, MD 20705

Phone:301-504-5680

Fax:301-504-6491

Email:dan.roberts@ars.usda.gov 


\begin{abstract}
Disease control tactics that rely less on synthetic pesticides are needed that are consistently effective in soils that vary with regard to their biotic and abiotic components. An ethanol extract of Serratia marcescens N4-5, when applied as a cucumber seed treatment, effectively suppressed damping-off of cucumber caused by Pythium ultimum in a natural sandy loam soil and a natural sand soil but not in a natural loam soil. A combination treatment containing seed treatment with this N4-5 ethanol extract and a drench containing Trichoderma virens GL21 improved disease control performance relative to individual application of both of the treatment components. Plant stand associated with this combination treatment was significantly greater than the no-treatment control in all three natural soils at all levels of pathogen inoculum used. In some cases plant stand associated with this combination treatment was significantly greater than that resulting from individual application of N4-5 ethanol extract or T. virens GL21. Data presented here indicate that strategic combinations of biologically based disease control tactics can increase consistency of performance in multiple soils that vary in biotic and abiotic characteristics.
\end{abstract}

Key words: cover crops, natural products, Pythium ultimum, seed treatments, Trichoderma virens

\title{
1. Introduction
}

Pythium ultimum Trow is an important soil-borne oomycete that causes disease under favorable environmental conditions on greater than 300 diverse plant species (Kamoun et al., 2015; Okubara et al., 2014). Seed treatment with pesticides, especially mefenoxam when available, 
can be very effective in managing damping-off caused by this pathogen (Garzón et al., 2011). However, there are concerns regarding the development of resistance to pesticides in pathogen populations (Lamour and Hausbeck, 2000; Moorman and Kim, 2004; Okubara et al., 2014; Taylor et al., 2002). Alternate control measures such as crop rotation can be ineffective due to the large host range of $P$. ultimum and the ability of this pathogen to persist in soil for extensive periods of time. Resistant cultivars can be a powerful tactic for disease control, however, cultivars resistant to this pathogen are limited in effectiveness (Louws et al., 2010; Okubara et al., 2014).

In prior work, we demonstrated the ability of seed treatment with cell-free ethanol extract of Serratia marcescens Bizio N4-5 to provide suppression of damping-off of cucumber caused by $P$. ultimum (Roberts et al., 2007; 2014; 2016). Seed treatment with N4-5 ethanol extract has potential for use in cucumber production systems as it resulted in suppression of damping-off caused by $P$. ultimum that was equivalent to that provided by the seed treatment pesticide Thiram in certain planting media and had a shelf-life of at least 14 weeks (Roberts et al., 2014). This work was focused on seed treatment due to the fact that some crops, such as cucumber, have a very short window of vulnerability to this disease and hence an infection court limited in time and space; allowing inundation of the infection court with N4-5 ethanol extract at the time of seed treatment (Fukui et al., 1994; Hadar et al., 1983; Nelson, 1988; Roberts et al., 1997; 2007; Windstam and Nelson, 2008).

Biologically based control tactics, such as N4-5 ethanol extract, and other tactics directed at control of soil-borne pathogens must be tested in a number of soils as biotic (e.g. genetic structure of target and non-target pathogen populations and soil microbial community) and abiotic (e.g. pH, mineral content, oxygen tensions) factors in soil can influence disease control 
efficacy and consistency (Roberts and Kobayashi, 2011). Indeed, N4-5 ethanol extract provided inconsistent control of damping-off of cucumber caused by $P$. ultimum between two different natural soils in past experiments (Roberts et al., 2016). Control associated with seed treatment with N4-5 ethanol extract was equivalent to that provided by seed treatment with Thiram in a sandy loam soil but ineffective and inconsistent in a loam soil.

Here we tested combinations of N4-5 ethanol extract with other biologically based control measures for increased efficacy and consistency of control of damping-off of cucumber caused by $P$. ultimum in several natural soils. It is thought that combinations of biologically based disease control tactics can improve consistency of performance (Lemanceau and Alabouvette, 1991; Pierson and Weller, 1994; Raupach and Kloepper, 1998). Specifically, we i) screened cover crops for suppression of damping-off of cucumber caused by P. ultimum. Chemical compounds released from cover crops affect plant pathogens and pests, and other soil microbes (Akhtar and Malik, 2000; Bailey and Lazarovits, 2003; McSorley, 2011; Zhou and Everts, 2004). We also ii) tested combinations of seed treatment with N4-5 ethanol extract, cover crops identified in this screen, and a biological control isolate of Trichoderma virens that was shown to be compatible with N4-5 ethanol extract (Roberts et al., 2005; 2016) for increased consistency of disease control over soils that differed in abiotic and biotic characteristics.

\section{Materials and methods}

\subsection{Preparation of cover crop biomass}

BMR sorghum-sudangrass (Sorghum bicolor $\times$ S. bicolor var. Sudanese), sunn hemp (Crotalaria juncea cv. Tillage Sunn), velvet bean (Mucuna pruriens), jack bean (Canavalia ensiformis), an 
Indian mustard (Brassica juncea) + white mustard (Sinapis alba) mixture, Martigena (Brassica hirta cv. Martigena), oilseed radish (Raphanus sativus), and Dwarf Essex rape (Brassica napus) were grown in $14 \times 20$ inch flats containing commercial potting mix (Pro-Mix PGX, Premier Horticulture, Inc., Quakertown, PA) for 16 weeks (cover crops were starting to flower) in the greenhouse, the shoots harvested, dried for 10 days at $160{ }^{\circ} \mathrm{C}$, ground with a Wiley mill (\#20 mesh screen), and stored in the dark at room temperature until used. All seeds were from Johnny's Select Seeds, Winslow, ME with the exception of velvet bean and jack bean which were the gift of Dr. Waldy Klassen (retired), Univ. FL Tropical Research and Education Center, Homestead, FL.

\subsection{Microbial strains, seed treatments, and formulations}

S. marcescens N4-5, Enterobacter cloacae 501R3, Pseudomonas protegens $\mathrm{Pf-5}$, and Trichoderma virens GL21 have all been shown to control P. ultimum on cucumber (Loper et al., 2007; Roberts et al., 1997; 2005; 2007). Strains N4-5, 501R3, and Pf-5 were routinely grown on nutrient broth (NB) or nutrient agar (NA) while isolate GL21 was grown on potato dextrose agar. P. ultimum Puzc is pathogenic on cucumber (Roberts et al., 1997; 2005; 2007) and was maintained on corn meal agar at room temperature. All microbial isolates were from the USDAARS, Sustainable Agricultural Systems culture collection.

Dried ethanol extract was prepared from S. marcescens N4-5 grown on peptone glycerol (PG) agar plates at $28^{\circ} \mathrm{C}$ as described (Matsuyama et al., 1985; Roberts et al., 2007). For treatment of cucumber seed (Cucumis sativum cv. Marketmore 76; no pesticide), dried N4-5 ethanol extract was resuspended in ethanol, incubated with seed for $30 \mathrm{~s} \mathrm{(4} \mathrm{PG} \mathrm{agar} \mathrm{plates}$ produced $2 \mathrm{~mL}$ ethanol extract which treated $3.5 \mathrm{~g}$ seed), and dried under a laminar flow hood. 
The control was seed incubated in ethanol but no N4-5 ethanol extract. E. cloacae 501R3 and $P$. protegens $\mathrm{Pf}-5$ were grown overnight in $\mathrm{NB}$, washed and resuspended in sterile distilled water (SDW), and applied to seed in a gelatin formulation essentially as described (Roberts et al., 2005). Seed coated with gelatin plus SDW, but no microbes, was the control. Formulated $T$. virens GL21 was prepared on Biodac (Kadant Gran Tek, Inc., Green Bay, WI) in mycobags (Unicorm Imp. and Mfg. Corp., Commerce, TX) as described by Roberts et al. (2010). For preparation of drenches for in-furrow application of $T$. virens, $50 \mathrm{~g}$ Biodac formulation was suspended in $200 \mathrm{~mL}$ SDW and ground with a tissue homogenizer (Ultra-Turrax T 25 basic, IKA-Werke, Staufen, Germany) prior to application. The control was sterile Biodac in SDW.

\subsection{Abiotic and biotic characterization of natural soils}

Physical-chemical characteristics of natural soils \#2 (Ultisol, loam, 106 ppm available P, 48 ppm K, 50 ppm Mg, 250 ppm Ca, 3.1 CEC, 3.0\% organic matter, pH 4.5), \#11 (Ultisol, sandy loam, 108 ppm available P, 141 ppm K, 60 ppm Mg, 620 ppm Ca, 6.3 CEC, 4.8\% organic matter, pH 5.1), \#13 (Ultisol, sand, 12 ppm available P, 40 ppm K, 65 ppm Mg, 240 ppm Ca, 4.0 CEC, 2.3\% organic matter, pH 4.7), \#15 (Inceptisol, loam, 41 ppm available P, 134 ppm K, 105 ppm Mg, 480 ppm Ca, 5.8 CEC, 1.4\% organic matter, pH 5.1), and \#18 (Ultisol, sandy loam, 32 ppm available P, 31 ppm K, 45 ppm Mg, 170 ppm Ca, 3.1 CEC, 2.7\% organic matter, pH 4.6) were determined by A\&L Eastern Laboratories, Inc. (Richmond, VA). All soils were collected from the Beltsville Agricultural Research Center.

For determination of differences in the soil microbial community between treatments, sunn hemp and sorghum-sudangrass cover crops, prepared as above, were mixed with natural soils \#2, \#11, \#13,\#15, and \#18 at a rate of $0.5 \%(w / w)$, or no cover crop was added, the soils 
incubated for three days at $22{ }^{\circ} \mathrm{C}$, and applied on top of potting mix in cups as indicated below. Cucumber seed was layered on top of the soil and a layer of soil treatment applied on top of the seed. Cups containing these treatments were incubated in the growth chamber at $22{ }^{\circ} \mathrm{C}$ for 14 days as for the disease assay described below. Soil microbial biomass and community composition were determined by phospholipid fatty acid (PLFA) analysis according to a previously published protocol (Buyer and Sasser, 2012). The experiment was performed twice with treatments replicated three times. Experiments were analyzed independently.

\subsection{Suppression of damping-off of cucumber caused by P. ultimum}

Experiments to determine suppression of damping-off of cucumber caused by $P$. ultimum were performed essentially as described (Roberts et al., 2005; 2007; 2016) using potting mix and natural soils \#2, \#13,\#15, and \#18 as the planting medium. Differences in abiotic and biotic characteristics of these soils are listed above and in Fig. 1. Formulations and cucumber seed treatments were prepared as described above. Treatments applied are stated in Tables 1 through

6. Treatments containing cover crops had cover crops mixed homogeneously into the planting medium at $0.5 \%(w / w)$ three days prior to infestation with $P$. ultimum. The Biodac granular formulation used in these experiments contained approximately $7.0 \log _{10} \mathrm{CFU} T$. virens per $\mathrm{g}$, with $1 \mathrm{~g}$ being applied to the seed region as a drench. Seed treated with live bacteria contained approximately $7.0 \log _{10} \mathrm{CFU}$ per seed.

To produce sporangia, $P$. ultimum was grown at $25^{\circ} \mathrm{C}$ for 3 days, flooded with sterile soil extract (Ayers and Lumsden, 1975), and incubated at $25^{\circ} \mathrm{C}$ for 7 to 28 days. Sporangia from these plates were washed and incorporated into potting mix. Potting mix, potting mix incorporated with cover crop (where appropriate) amended with sporangia of $P$. ultimum or 
with SDW, treated seeds or non-treated seeds, and potting mix amended with sporangia of $P$.

ultimum or SDW, were added sequentially as layers to 6-cm-diam. cups as described by Roberts et al. (1997). Potting-mix, natural soil incorporated with cover crop (where appropriate) amended with sporangia of $P$. ultimum or with SDW, treated seeds or non-treated seeds, and natural soil amended with sporangia of $P$. ultimum or SDW were added sequentially as layers to the 6-cm-diameter cups in experiments containing natural soils. For each treatment, eight replicate cups were sown with five seeds each and incubated in a growth chamber at $22{ }^{\circ} \mathrm{C}$ for 14 days with a $12 \mathrm{~h}$ photoperiod. Treatments were arranged in a completely randomized design. Mean plant stand per cup for each treatment was determined, subjected to ANOVA, and differences among means estimated using least significant difference in SAS (SAS, Cary, NC). Experiments were performed at least two times and analyzed independently only if there was a significant experiment $\times$ treatment interaction $(P \leq 0.05)$.

\section{Results}

\subsection{Screening cover crops with and without seeds treated with bacterial biological control} agents for suppression of damping-off in potting mix

Dried, ground cover crop preparations incorporated into the potting mix (sorghumsudangrass, sunn hemp, velvet bean, jack bean) were tested alone or in combination with seed treatments containing the bacteria $E$. cloacae 501R3 or P. protegens $\mathrm{Pf}-5$ for suppression of damping-off caused by P. ultimum (Table 1). All cover crop treatments either tested alone, or in these combinations, provided a plant stand significantly greater than the no-treatment control at the lower level of pathogen inoculum. However, at the higher level of $P$. ultimum inoculum, only sorghum-sudan grass in combination with seed treatment with 501R3, velvet bean alone, 
and velvet bean in combination with seed treatment with 501R3 provided significant disease suppression relative to the no-treatment control.

A second set of three experiments was performed with the dried, ground cover crop preparations Indian mustard + white mustard mixture, Martigena, oilseed radish, and Dwarf Essex rape. These cover crop preparations were incorporated into the potting mix and tested alone or in combination with seed treatment with 501R3 or Pf-5 (data not shown). Experiments could not be combined prior to analysis due to a significant experiment $\times$ treatment interaction $(P=0.0096)$. None of these treatments provided consistent suppression of damping-off in these three experiments. Dwarf Essex rape was the only cover crop preparation applied alone that resulted in a plant stand significantly greater than that of the no-treatment control, and this occurred in only one of the three experiments at the low level of inoculum of $P$. ultimum (10 sporangia per cc). Three treatments containing cover crop preparations applied in combination with seed treatment with a bacterial biological control agent (Indian mustard + white mustard mixture + Pf-5, Martigena + Pf-5, oilseed radish + Pf-5) provided significant suppression of damping-off in two of three experiments when the higher level of inoculum (25 sporangia per cc) was used but not when the lower level of inoculum (10 sporangia per cc) was used.

\subsection{Suppression of damping-off of cucumber in potting mix with S. marcescens N4-5 ethanol}

extract, T. virens GL21, sorghum-sudangrass, sunn hemp, and E. cloacae 501R3

Treatments containing N4-5 ethanol extract, isolate GL21, sorghum-sudangrass, sunn hemp, and strain 501R3 were tested alone or in combinations. Other cover crops from the initial screen were not tested in the natural soils as they provided inconsistent performance in the screen or were not commercially available in the mid-Atlantic region of the United 
States. N4-5 ethanol extract applied as a seed treatment, GL21 applied to the seed area as a drench, and sorghum-sudangrass incorporated in the potting mix all provided significant suppression of damping-off when applied individually with at least two of the three levels of inoculum of P. ultimum (Table 2). Seed treatment with N4-5 ethanol extract was the best individual treatment providing significantly greater $(P<0.05)$ control than sorghum-sudangrass, GL21, or 501R3 at the higher two levels of inoculum. Combination treatments containing N4-5 ethanol extract and sorghum-sudangrass or GL21 were the only treatments that resulted in a plant stand that was similar to the healthy check.

Three experiments were also performed using sunn hemp as the cover crop, however, they could not be combined prior to statistical analysis due to a significant experiment $x$ treatment interaction (Table 3). N4-5 ethanol extract applied alone did not provide disease control in experiment 1 , resulted in a plant stand that was significantly greater $(P<0.05)$

than the no-treatment control and similar to the healthy check at all three levels of inoculum of P. ultimum in experiment 2 , and resulted in a plant stand that was significantly greater than the no-treatment control at all three levels of inoculum in experiment 3. The sunn hemp treatment and GL21 treatment also provided inconsistent results over these three experiments. Each of these treatments provided disease control in two of the three experiments at one or more levels of inoculum of $P$. ultimum. The treatment containing 501R3 applied to cucumber seed provided disease control in experiment 1 only.

Combining the N4-5 ethanol extract seed treatment with the sunn hemp treatment or GL21 applied to the seed region as a drench provided more consistent control over these three experiments than their individual applications (Table 3). N4-5 ethanol extract combined with the sunn hemp treatment resulted in a plant stand that was significantly greater than the no- 
treatment control at all levels of pathogen inoculum in all three experiments, with the exception of one level of inoculum (70 sporangia per cc) in experiment 1 . N4-5 ethanol extract combined with the GL21 treatment also resulted in a plant stand that was significantly greater than the notreatment control at all levels of pathogen inoculum in all three experiments with the exception of one inoculum level (40 sporangia per cc) in experiment 1. Similar results were obtained when sunn hemp incorporated into the potting mix was combined in a treatment with GL21. Sunn hemp combined with seed treatment with 501R3 also provided disease control, but not as consistently as with the other combination treatments.

\subsection{Suppression of damping-off of cucumber in four natural soils with $\mathrm{S}$. marcescens N4-5}

ethanol extract, T. virens GL21, sorghum-sudangrass, and sunn hemp

These biologicals, applied alone or in combination, were compared with the Thiram seedtreatment chemical control for suppression of damping-off of cucumber in four natural soils. The natural soils tested (soils \#2, \#13, \#15, and \#18) had different biotic characteristics in experiment 1 (Fig. 1) and experiment 2 (data not shown). Soil \#18 was an outlier with regard to microbial community in both experiments. Decomposition of variance analysis indicated that soil and treatment (cover crop) were responcible for $44.5 \%(P=0.002)$ and $13 \%(P=0.008)$ of the variation in the microbial community in experiment 1 and $44.3 \%(P$ $=0.002)$ and $4.5 \%(P=0.38)$ of the variation in experiment 2 , respectively. These soils also varied in abiotic characteristics (see Fig. 1). Disease pressure varied with these soils; soils \#2, $\# 13$, and \#15 being conducive to disease (Tables 4, 5, and 6) while soil \#18 was not. There was insufficient disease pressure in soil \#18 despite adding the same inoculum levels to this soil that were added to the other three (data not shown). 
N4-5 ethanol extract applied as a seed treatment provided disease suppression when the two lower levels of inoculum of $P$. ultimum were applied to soil \#2, a sandy loam soil (Table 4). Plant stand associated with this treatment was significantly greater than the no-treatment control at these levels of inoculum. Plant stand with the N4-5 ethanol extract treatment was also similar to the healthy check at these levels of inoculum and to the Thiram control. However, disease suppression provided by the N4-5 ethanol extract treatment was significantly lower than that provided by the Thiram control at the highest level of inoculum of $P$. utlimum. Isolate GL21 applied alone as a drench to the seed area provided disease suppression at all levels of inoculum in soil \#2 (Table 4). However, disease suppression was similar to the Thiram control at only the lowest level of inoculum. Individual treatments containing sorghum-sudangrass or sunn hemp incorporated into the soil provided no disease suppression or only at the lowest level of inoculum in soil \#2, respectively. Combining N4-5 ethanol extract with the isolate GL21 treatment provided the best disease suppression in soil \#2. This combination treatment was the only treatment where plant stand was similar to that of the healthy check at all levels of inoculum and to that of the Thiram control. The Thiram control did not provide a plant stand similar to the healthy check at the highest level of inoculum in this soil (Table 4).

The same treatments were tested for suppression of damping-off of cucumber caused by P. ultimum in soil \#13, a sand soil (Table 5). The two experiments with this soil could not be combined due to a significant experiment $\times$ treatment interaction $(P=0.0052)$. In experiment 1 the N4-5 ethanol extract seed treatment provided significant disease suppression relative to the no-treatment control at all levels of inoculum tested. This level of disease suppression was similar to that provided by the Thiram control at the lower two levels, but not the highest level of inoculum. Additionally, the Thiram control resulted in a plant stand that was similar to the 
healthy check at all levels of inoculum while the N4-5 ethanol extract treatment never did. This N4-5 ethanol extract seed treatment resulted in a plant stand that was similar to that provided by the Thiram control and the healthy check at all levels of inoculum in experiment 2 . The isolate GL21 drench performed poorly in experiment 1 in soil \#13 not providing disease suppression at any level of inoculum tested. In experiment 2 the isolate GL21 treatment performed better, providing disease control at both levels of inoculum tested. Sorghum-sudan grass and sunn hemp provided poor disease suppression when incorporated into this soil. Each only provided significant disease suppression relative to the no-treatment control at only one level of inoculum of P. ultimum over both experiments 1 and 2 (Table 5).

Combining N4-5 ethanol extract in a treatment with isolate GL21, sorghum-sudan grass, or sunn hemp or in a triple combination treatment with isolate GL21 and sorghum-sudan grass improved disease suppression over the individual application of any of these treatments in soil \#13 in experiment 1 (Table 5). Each of these combination treatments provided plant stand that was similar to the healthy check with at least one level of inoculum tested in this soil whereas no individual treatment did. The best overall biologically based treatment in soil \#13 in experiment 1 was the combination of N4-5 ethanol extract seed treatment with the isolate GL21 drench and sorghum-sudan grass incorporated into the soil. Plant stand with this triple combination treatment was similar to that of the healthy check and the Thiram-treated seed control at all levels of inoculum. The N4-5 ethanol extract treatment resulted in a plant stand that was similar to the healthy check at all levels of $\boldsymbol{P}$. ultimum inoculum in soil \#13 in experiment 2 making it difficult to determine if combining N4-5 ethanol extract in a treatment containing another biological improved disease control (Table 5). 
The same treatments were also tested for suppression of damping-off of cucumber caused by P. ultimum in soil \#15, a loam soil (Table 6). The two experiments with this soil could not be combined due to a significant experiment $\times$ treatment interaction $(P<0.0001)$. The N4-5 ethanol extract treatment provided significant disease suppression relative to the no-treatment control at all levels of inoculum in experiment 1 and at the mid level of inoculum in experiment 2. Plant stand associated with the N4-5 ethanol extract treatment was similar to that associated with the Thiram control with all levels of inoculum tested over both experiments. Isolate GL21 did not provide disease suppression at any level of inoculum tested in experiment 1 in soil \#15 (Table 6). In experiment 2, isolate GL21 provided disease suppression at all levels of inoculum tested. Sorghum-sudan grass and sunn hemp incorporated into this soil individually did not provide significant disease suppression at any level of inoculum in either experiment in soil \#15.

When combination treatments were tested in soil \#15 only combining N4-5 ethanol extract with sorghum-sudan grass and isolate GL21 substantially improved performance over the treatment containing N4-5 ethanol extract alone (Table 6). Plant stand associated with this triple combination treatment was always greater than the no-treatment control at all levels of inoculum over both experiments 1 and 2 and was similar to the healthy check at the low level of inoculum in experiment 1 and at all levels of inoculum in experiment 2. In general, the treatments containing N4-5 ethanol extract and a second biological did not provide the same level of disease suppression as this triple combination treatment.

Soil \#18 was not conducive to damping-off of cucumber caused by $P$. ultimum in either of the two experiments conducted with this soil so disease suppression by the treatments could not be evaluated. There was no evidence of phytotoxicity associated with any treatment in this soil (data not shown). 


\section{Discussion}

Seed treatment with ethanol extract of cell mass of $S$. marcescens N4-5 was more consistently effective in suppressing damping-off of cucumber caused by P. ultimum than the other biologically based treatments when treatments were applied individually. Experiments were performed in natural soils that varied in biotic and abiotic characteristics. In the presence of inoculum of $P$. ultimum in the three natural soils that were conducive to disease the N4-5 ethanol extract, isolate GL21, sorghum-sudangrass, and sunn hemp treatments resulted in a plant stand significantly greater than the no-treatment control $80 \%, 57 \%, 7 \%$, and $14 \%$ of the time, respectively, when all levels of inoculum were considered. The Thiram control significantly increased plant stand relative to the no-treatment control $93 \%$ of the time

(Tables 4, 5, 6). Suppression of damping-off disease of cucumber with seeds treated with N4-5 ethanol extract was only inconsistent in one soil, a loam soil (\#15). Inconsistent disease suppression in this soil also occurred in prior experiments (Roberts et al., 2016). It is not known why N4-5 ethanol extract provided inconsistent disease suppression in this loam soil. However, mineral content and other abiotic soil factors as well as differences in the composition and resident activity of the indigenous microflora are known to influence disease caused by $P$. ultimum, the persistence of biological treatments in soil, and the effectiveness of biologically based disease control tactics (Boehm and Hoitink, 1992; Craft and Nelson, 1996; Duffy and DeFago, 1997; Duffy et al., 1997; Hancock, 1979; McSorley, 2011).

Combining the N4-5 ethanol extract seed treatment with T. virens GL21 applied as a drench to the seed area improved disease suppression relative to these two treatments applied individually. Plant stand associated with this combination treatment was significantly greater 
than the no-treatment control in the presence of pathogen at all inoculum levels in all soils (100\% of the time) that were conducive to damping-off. Plant stand associated with this combination treatment was significantly greater than that of N4-5 ethanol extract or $T$. virens GL21 treatments applied alone at the highest level of inoculum in soil \#2 and with at least one inoculum level in each experiment in soil \#13. Also, this combination treatment resulted in a plant stand similar to the healthy check $80 \%$ of the time while the N4-5 extract applied alone and isolate GL21 applied alone resulted in a plant stand similar to the healthy check $40 \%$ and $21 \%$ of the time, respectively. It is thought that the combination of microbial biological control treatments should reduce variability in disease control but there is insufficient evidence to support this claim (Guetsky et al., 2002; Xu and Jeger, 2013). Here we provide data that suggest that combinations of microbial biological control treatments can improve consistency of control over multiple soils that vary in biotic and abiotic characteristics.

Sorghum-sudangrass and sunn hemp did not effectively suppress this disease when incorporated in the natural soils tested here. It should be noted that dried, ground cover crop shoot preparations were used in these soils due to the long time span over which these experiments were conducted. It is possible that better disease suppression performance may be obtained with fresh cover crop preparations that contain the entire plant. The biochemical quality of organic soil amendments have been shown to affect suppression of pathogen populations (Bonanomi et al., 2013). The use of dried cover crops may have slowed their decomposition in soil and it has been reported that the use of undecomposed organic matter should be avoided for Pythium spp. (Bonanomi et al., 2007). Additionally, the drying process may have inactivated inhibitory compounds in the cover crops. 
The combination of biological control treatments and organic matter, in the form of compost, has resulted in increased disease suppressiveness in the past (Pugliese et al., 2011) and in complementing beneficial activities where the compost provided a substantial yield benefit and the biological control treatment reduced soilborne disease (Larkin and Tavantzis, 2013). However, there was no consistent increase in disease suppression associated with combining the N4-5 ethanol extract seed treatment with organic matter in the form of a cover crop (sunnhemp, sorghum-sudangrass) or with the treatment containing N4-5 ethanol extract, $T$. virens GL21, and the cover crop sorghum-sudangrass in the natural soils tested here. Cover crops can provide ecosystem services other than disease suppression including improving soil aggregate stability and infiltration, reducing soil erosion, weed suppression, and managing nitrogen fertility (Snapp et al., 2005). There were no consistent decreases in disease suppression detected with these combination treatments containing N4-5 ethanol extract and sorghum-sudangrass or sunn hemp relative to the individual treatment applications. Therefore, combinations of the N4-5 ethanol extract seed treatment with cover crops used for these other ecosystems services are possible as the N4-5 ethanol extract and at least the cover crops tested here were compatible for disease suppression.

Experiments reported here provide more support for the commercial viability of N4-5 ethanol extract for suppression of damping-off of cucumber caused by P. ultimum as this extract was effective in additional soils that varied in texture, mineral content, organic matter, and their indigenous microflora. Experiments reported here also support the use of strategic combinations of biologically based tactics for improved consistency of disease suppression; poor consistency of performance by biologically based disease control tactics being an impediment to their grower acceptance (Fravel, 2005; Glare et al., 2012). Further experiments need to be performed with 
additional soils with and without the addition of other pathogens of cucumber. These experiments should be conducted with these soils as the only planting medium so that the pathogens have the opportunity to infect plant parts spatially distant from the point of seed treatment (Roberts et al., 2016); something not allowed for with the inoculum sandwich technique used here.

\section{Acknowledgments}

We thank Stanley Tesch, Sustainable Agricultural Systems Laboratory, USDA-ARS, for excellent technical assistance characterizing natural soils. We also thank Dr. Waldy Klassen (retired), Univ. of Florida Tropical Research and Education Center, Homestead, FL for the gift of velvet bean and jack bean biomass and seed.

\section{References}

Akhtar, M., Malik, A., 2000. Roles of organic soil amendments and soil organisms in the biological control of plant-parasitic nematodes: a review. Bioresource Technol. 74, 35-47.

Ayers, W.A., Lumsden, R.D., 1975. Factors affecting production and germination of oospores of three Pythium species. Phytopathology 65, 1094-1100.

Bailey, K.L., Lazarovits, G., 2003. Suppressing soil-borne diseases with residue management and organic amendments. Soil Tillage Res. 72, 169-180.

Boehm, M.J., Hoitink, H.A.J., 1992. Sustenance of microbial activity in potting mixes and its impact on severity of Pythium root rot of Poinsettia. Phytopathology 82, 259-264. 


\section{Bonanomi, G., Antignani, V., Pane, C., Scala, F., 2007. Suppression of soilborne fungal diseases with organic amendments. J. Plant Pathol. 89, 311-324.}

\section{Bonanomi, G., Gaglione, S.A., Incerti, G., Zoina, A., 2013. Biochemical quality of organic amendments affects soil fungistasis. Appl. Soil Ecol. 72, 135-142.}

Buyer, J.S., Sasser, M., 2012. High throughput phospholipid fatty acid analysis of soils. Appl. Soil Ecol. 61, 127-130.

Craft, C.M., Nelson, E.B., 1996. Microbial properties of compost that suppress damping-off and root rot of creeping bentgrass caused by Pythium graminicola. Appl. Environ. Microbiol. 62, $1550-1557$.

Duffy, B.K., Défago, G., 1997. Zinc improves biocontrol of Fusarium crown and root rot of tomato by Pseudomonas fluorescens and represses the production of pathogen metabolites inhibitory to bacterial antibiotic biosynthesis. Phytopathology 87, 1250-1257.

Duffy, B.K., Ownley, B.H., Weller, D.M., 1997. Soil chemical and physical properties associated with suppression of take-all of wheat by Trichoderma koningii. Phytopathology 87, $1118-1124$. 
Fravel, D.R., 2005. Commercialization and implementation of biocontrol. Annu. Rev. Phytopathol. 43, 337-359.

Fukui, R., Campbell, G.S., Cook, R.J., 1994. Factors influencing the incidence of embryo infection by Pythium spp. during germination of wheat seeds in soils. Phytopathology 84, 695702.

Garzón, C.D., Molineros, J.E., Yánez, J.M., Flores, F.J., Jiménez-Gasco, Moorman, G.W., 2011. Sublethal doses of Mefenoxam enhance Pythium damping-off of geranium. Plant Dis. 95, 12331238.

Glare, T., Caradus, J., Gelernter, W., Jackson, T., Keyhani, N., Köhl, J., Marrone, P., Morin, L., Stewart, A., 2012. Have biopesticides come of age? Trends Biotechnol. $30,250-258$.

Guetsky, R., Shtienberg, D., Elad, Y., Fischer, E., Dinoor, A., 2002. Improving biological control by combining biological control agents each with several mechanisms of disease suppression. Phytopathology 92, 976-985.

Hadar, Y., Harman, G.E., Taylor, A.G., Norton, G.M., 1983. Effects of pregermination of pea and cucumber seeds and of seed treatment with Enterobacter cloacae on rots caused by Pythium spp. Phytopathology 73, 1322-1325. 
Hancock, J.G. 1979., Occurrence of soil suppressive to Pythium ultimum. Pages 183-180 in:

Soil-Borne Plant Pathogens. B. Schippers and W. Gams, eds. Academic Press, New York, N.Y.

Kamoun, S., Furzer, O., Jones, J.D.G., Judelson, H.S., Ali, G.S., Dalio, R.J.D., Roy, S.G.,

Schena, L., Zambounis, A., Panabières, F., Cahill, D., Ruocco, M., Figueiredo, A., Chan, X.-R., Hulvey, J., Stam, R., Lamour, K., Gijzen, M., Tyler, B.M., Grünwald, N.J., Mukhtar, M.S., Tomé, D.F.A., Tör, M., Van Den Ackerveken, G., McDowell, J., Daayf, F., Fry, W.E., Lindqvist-Kreuze, H., Meijer, H.J.G., Petre, B., Ristaino, J., Yoshida, K., Birch, P.R.J., Govers, F., 2014. The top 10 oomycete pathogens in molecular plant pathology. Molec. Plant Path. doi:10.1111/mpp.12190.

Lamour, K.H., Hausbeck, M.K., 2000. Mefenoxam insensitivity and the sexual stage of Phytophthora capsici in Michigan cucurbit fields. Phytopathology 90, 396-400.

\section{Larkin, R.P., Tavantzis, S., 2013. Use of biocontrol organisms and compost amendments for improved control of soilborne diseases and increased potato production. Amer. J.}

Potato Res. 90, 261-270.

Lemanceau, P., Alabouvette, C., 1991. Biological control of Fusarium diseases by fluorescent Pseudomonas and non-pathogenic Fusarium. Crop Prot. 10, 279-286. 
Loper, J.E., Kobayashi, D.Y., Paulsen, I.T., 2007. The genomic sequence of Pseudomonas fluorescens Pf-5: Insights into biological control. Phytopathology 97, 233-238.

Louws, F.J., Rivard, C.L., Kubota, C., 2010. Grafting fruiting vegetables to manage soilborne pathogens, foliar pathogens, arthropods and weeds. Sci. Hort. 127, 127-146.

Matsuyama, T., Fujita, M., Yano, I., 1985. Wetting agent produced by Serratia marcescens. FEMS Microbiol. Lett. 28, 125-129.

McSorley, R., 2011. Overview of organic amendments for management of plant-parasitic nematodes, with case studies from Florida. J. Nematol. 43, 69-81.

Moorman, G.W., Kim, S.H., 2004. Species of Pythium from greenhouses in Pennsylvania exhibit resistance to propamocarb and mefenoxam. Plant Dis. 88, 630-632.

Nelson, E.B., 1988. Biological control of Pythium seed rot and preemergence damping-off of cotton with Enterobacter cloacae and Erwinia herbicola applied as seed treatments. Plant Dis. $72,140-142$.

Okubara, P.A., Dickman, M.B., Blechl, A.E., 2014. Molecular and genetic aspects of controlling the soilborne necrotrophic pathogens Rhizoctonia and Pythium. Plant Sci. 228, 61-70.

Pierson, E.A., Weller, D.M., 1994. Use of mixtures of fluorescent pseudomonads to suppress take-all and improve the growth of wheat. Phytopathology 84, 940-947. 


\section{Pugliese, M., Liu, B., Gullino, M.L., Garabaldi, A., 2011. Microbial enrichment of compost with biological control agents to enhance suppressiveness to four soil-borne diseases in greenhouses. J. Plant Dis. Protect. 118, 45-50.}

Raupach, G.S., Kloepper, J.W., 1998. Mixtures of plant growth-promoting rhizobacteria enhance biological control of multiple cucumber pathogens. Phytopathology 88, 1158-1164.

Roberts, D.P., Dery, P.D., Hebbar, P.K., Mao, W., Lumsden, R.D., 1997. Biological control of damping-off of cucumber caused by Pythium ultimum with a root-colonization-deficient strain of Escherichia coli. J. Phytopathol. 145, 383-388.

Roberts, D.P., Lohrke, S.M., Meyer, S.L.F., Buyer, J.S., Bowers, J.H., Baker, C.J., Li, W., de Souza, J.T., Lewis, J.A., Chung, S., 2005. Biocontrol agents applied individually and in combination for suppression of soilborne diseases of cucumber. Crop Protect. 24, 141-155.

Roberts, D.P., McKenna, L.F., Lakshman, D.K., Meyer, S.L.F., Kong, H., de Souza, J.G., Lydon, J., Baker, C.J., Chung, S., 2007. Suppression of damping-off of cucumber caused by Pythium ultimum with live cells and extracts of Serratia marcescens. Soil Biol. Biochem. 39, 2275-2288.

Roberts, D.P., Maul, J.E., McKenna, L.F., Emche, S.E., Meyer, S.L.F., Collins, R.T., Bowers, J.H., 2010. Selection of genetically diverse Trichoderma spp. isolates for suppression of Phytophthora capsici on bell pepper. Can. J. Microbiol. 56, 864-873. 
Roberts, D.P., Kobayashi, D.Y., 2011. Impact of spatial heterogeneity within spermosphere and rhizosphere environments on performance of bacterial biological control agents. Pages 111-130 in: Bacteria in Agrobiology: Crop Ecosystems. D.K. Maheshwari, ed. Springer Verlag, New York, NY.

Roberts, D.P., Lakshman, D.K., Maul, J.E., McKenna, L.F., Buyer, J.S., Fan, B., 2014. Control of damping-off of organic and conventional cucumber with extracts from a plant-associated bacterium rivals a seed treatment pesticide. Crop Prot. 65, 86-94.

Roberts, D.P., Lakshman, D.K., McKenna, L.F., Emche, S.E., Maul, J.E., Bauchan, G., 2016. Seed treatment with ethanol extract of Serratia marcescens is compatible with Trichoderma isolates for control of damping-off of cucumber caused by Pythium ultimum. Plant Dis. 100, $1278-1287$.

Snapp, S.S., Swinton, S.M., Labarta, R., Mutch, D., Black, J.R., Leep, R., Nyiraneza, J., O’Neil, K., 2005. Evaluating cover crops for benefits, costs and performance within cropping system niches. Agron. J. 97, 322-332.

Taylor, R.J., Salas, B., Secor, G.A., Rivera, V., Gudmestad, N.C., 2002. Sensitivity of north American isolates of Phytophthora erythroseptica and Pythium ultimum to mefenoxam (metalaxyl). Plant Dis. 86, 797-802. 
Windstam, S., Nelson, E.B., 2008. Differenetial interference with Pythium ultimum sporangium activation and germination by Enterobacter cloacae in the corn and cucumber spermospheres. Appl. Environ. Microbiol. 74, 4285-4291.

Xu, X.-M., Jeger, M.J., 2013. Theoretical modeling suggests that synergy may result from combined use of two biocontrol agents for controlling foliar pathogens under spatial heterogeneous conditions. Phytopathology 103, 768-775.

Zhou, X.G., Everts, K.L., 2004. Suppression of Fusarium Wilt of watermelon by soil amendment with hairy vetch. Plant Dis. 88, 1357-1365. 


\section{Table 1}

Suppression of damping-off of cucumber caused by Pythium ultimum with Enterobacter cloacae 501R3 and Pseudomonas protegens Pf-5 combined with cover crops in potting mix.

$\underline{\text { Mean plant stand at different } P . \text { ultimum infestation levels per pot }}{ }^{\mathrm{a}}$

Treatment $^{\mathrm{b}}$

No treatment

SSG

$\mathrm{SSG}+\mathrm{Pf}-5$

$\mathrm{SSG}+501 \mathrm{R} 3$

SH

$\mathrm{SH}+\mathrm{Pf}-5$

$\mathrm{SH}+501 \mathrm{R} 3$

VB

$\mathrm{VB}+\mathrm{Pf}-5$
Level P. ultimum ${ }^{c}$ :

0

10

25

$\begin{array}{lll}4.88 \mathrm{~A} & 2.08 \mathrm{NO} & 2.17 \mathrm{MNO} \\ 4.67 \mathrm{~A} \rightarrow \mathrm{D} & 2.75 \mathrm{I} \rightarrow \mathrm{O} & 2.63 \mathrm{~J} \rightarrow \mathrm{O} \\ \mathrm{ND}^{\mathrm{d}} & 2.54 \mathrm{~K} \rightarrow \mathrm{O} & 2.08 \mathrm{NO} \\ \mathrm{ND} & 3.83 \mathrm{C} \rightarrow \mathrm{G} & 3.79 \mathrm{C} \rightarrow \mathrm{G} \\ 4.83 \mathrm{~A} & 3.50 \mathrm{E} \rightarrow \mathrm{J} & 2.50 \mathrm{~L} \rightarrow \mathrm{O} \\ \mathrm{ND} & 2.71 \mathrm{I} \rightarrow \mathrm{O} & 1.92 \mathrm{O} \\ \mathrm{ND} & 3.54 \mathrm{E} \rightarrow \mathrm{J} & 2.79 \mathrm{H} \rightarrow \mathrm{O} \\ 4.71 \mathrm{ABC} & 3.88 \mathrm{~B} \rightarrow \mathrm{F} & 3.13 \mathrm{~F} \rightarrow \mathrm{L} \\ \mathrm{ND} & 3.50 \mathrm{E} \rightarrow \mathrm{J} & 2.50 \mathrm{~L} \rightarrow \mathrm{O}\end{array}$




$\begin{array}{llll}\mathrm{VB}+501 \mathrm{R} 3 & \mathrm{ND} & 4.29 \mathrm{~A} \rightarrow \mathrm{E} & 3.71 \mathrm{E} \rightarrow \mathrm{H} \\ \mathrm{JB} & 4.79 \mathrm{AB} & 3.58 \mathrm{E} \rightarrow \mathrm{I} & 2.92 \mathrm{~K} \rightarrow \mathrm{N} \\ \mathrm{JB}+\mathrm{Pf}-5 & \mathrm{ND} & 2.96 \mathrm{~F} \rightarrow \mathrm{N} & 2.18 \mathrm{~L} \rightarrow \mathrm{O} \\ \mathrm{JB}+501 \mathrm{R} 3 & \mathrm{ND} & 3.75 \mathrm{D} \rightarrow \mathrm{G} & 2.96 \mathrm{~F} \rightarrow \mathrm{N} \\ \mathrm{Pf}-5 & \mathrm{ND} & 2.04 \mathrm{NO} & 2.33 \mathrm{~L} \rightarrow \mathrm{O} \\ 501 \mathrm{R} 3 & \mathrm{ND} & 3.45 \mathrm{E} \rightarrow \mathrm{K} & 3.04 \mathrm{~F} \rightarrow \mathrm{M}\end{array}$

${ }^{a}$ Values are the mean of three experiments $(n=3)$ expressed as mean plant stand per pot. Results were combined prior to analysis as there was no significant experiment $\times$ treatment interaction $(P=0.0893)$. Treatments in all three experiments contained eight replicate pots, each containing five seeds. Numbers followed by the same letter are not significantly different $(P \leq 0.05)$ as determined by least significant difference. Least significant difference was 0.9434.

${ }^{b}$ No treatment indicates that cucumber seeds were not treated prior to being sown and there were no cover crop or bacterial applications. SSG, sorghum-sudangrass; Pf-5, P. protegens Pf-5 applied as a seed treatment; 501R3, E. cloacae 501R3 applied as a seed treatment; SH, sunn hemp; VB, velvet bean; JB, jack bean. All cover crops were incorporated into the potting mix.

${ }^{\mathrm{c}}$ Quantity of sporangia of $P$. ultimum per $\mathrm{cm}^{3}$ of potting mix inoculum.

${ }^{\mathrm{d}} \mathrm{ND}$, not determined. 
Table 2

Suppression of damping-off of cucumber caused by Pythium ultimum with various treatments containing sorghum-sudangrass, ethanol extract of Serratia marcescens N4-5, Trichoderma virens GL21, or Enterobacter cloacae 501R3 in potting mix.

$\underline{\text { Mean plant stand per pot at different } P . \text { ultimum infestation levels }{ }^{\mathrm{a}}}$

\begin{tabular}{|c|c|c|c|c|}
\hline Treatment $^{\mathrm{b}}$ & Level P. ultimum ${ }^{c}$ : & 20 & 40 & 70 \\
\hline No treatment & $5.00 \mathrm{~A}$ & $1.17 \mathrm{~J} \rightarrow \mathrm{M}$ & $0.29 \mathrm{MN}$ & $0.17 \mathrm{~N}$ \\
\hline SSG & $4.88 \mathrm{~A}$ & $3.50 \mathrm{~B} \rightarrow \mathrm{E}$ & $1.71 \mathrm{H} \rightarrow \mathrm{L}$ & $1.58 \mathrm{I} \rightarrow \mathrm{L}$ \\
\hline N4-5 extract & $4.94 \mathrm{~A}$ & $3.58 \mathrm{~B} \rightarrow \mathrm{E}$ & $3.41 \mathrm{~B} \rightarrow \mathrm{E}$ & $3.25 \mathrm{CDE}$ \\
\hline $501 \mathrm{R} 3$ & $4.81 \mathrm{~A}$ & $1.63 \mathrm{I} \rightarrow \mathrm{L}$ & $0.96 \mathrm{~K} \rightarrow \mathrm{N}$ & $0.75 \mathrm{LMN}$ \\
\hline GL21 & $4.88 \mathrm{~A}$ & $2.79 \mathrm{D} \rightarrow \mathrm{G}$ & $1.92 \mathrm{G} \rightarrow \mathrm{K}$ & $0.75 \mathrm{LMN}$ \\
\hline SSG + N4-5 extract & $4.71 \mathrm{~A}$ & $4.13 \mathrm{ABC}$ & $4.92 \mathrm{~A}$ & $3.63 \mathrm{BCD}$ \\
\hline $\mathrm{SSG}+501 \mathrm{R} 3$ & $4.83 \mathrm{~A}$ & $1.83 \mathrm{G} \rightarrow \mathrm{K}$ & $2.21 \mathrm{~F} \rightarrow \mathrm{I}$ & $1.96 \mathrm{G} \rightarrow \mathrm{J}$ \\
\hline SSG + GL21 & $4.88 \mathrm{~A}$ & $3.25 \mathrm{CDE}$ & $3.04 \mathrm{DEF}$ & $2.63 \mathrm{E} \rightarrow \mathrm{H}$ \\
\hline N4-5 extract + GL21 & $4.33 \mathrm{AB}$ & $4.75 \mathrm{~A}$ & 4.13 $\mathrm{ABC}$ & 3.71 BCD \\
\hline
\end{tabular}


${ }^{a}$ Values are the mean of three experiments $(n=3)$ expressed as mean plant stand per pot. Results were combined prior to analysis as there was no significant experiment $\times$ treatment interaction $(P=0.0804)$. Treatments in all three experiments contained eight replicate pots, each containing five seeds. Numbers followed by the same letter are not significantly different $(P \leq 0.05)$ as determined by least significant difference. Least significant difference was 0.9594.

${ }^{\mathrm{b}}$ No treatment indicates that cucumber seeds were not treated prior to being sown and there were no cover crop or T. virens GL21 applications. SSG, sorghum-sudangrass incorporated into the potting mix; N4-5 extract, ethanol extract of S. marcescens N4-5 applied as a seed treatment; 501R3, E. cloacae 501R3 applied as a seed treatment; GL21, T. virens GL21 applied in furrow as a drench.

${ }^{c}$ Quantity of sporangia of $P$. ultimum per $\mathrm{cm}^{3}$ of potting mix inoculum. 


\section{Table 3}

Suppression of damping-off of cucumber caused by Pythium ultimum with various treatments containing sunn hemp, ethanol extract of Serratia marcescens N4-5, or Trichoderma virens GL21, or Enterobacter cloacae 501R3 in potting $\operatorname{mix}^{\mathrm{a}}$.

\section{Experiment 1}

$\underline{\text { Mean plant stand per pot at different } P \text {. ultimum infestation levels }}{ }^{\mathrm{c}}$

Treatment $\mathrm{t}^{\mathrm{b}}$

No treatment

$\mathrm{SH}$

N4-5 extract

501R3

GL21

$\mathrm{SH}+\mathrm{N} 4-5$ extract

$\mathrm{SH}+501 \mathrm{R} 3$

$\mathrm{SH}+\mathrm{GL} 21$

$\mathrm{N} 4-5$ extract + GL21
0

$4.00 \mathrm{AB}$

$4.25 \mathrm{~A}$

$3.13 \mathrm{~A} \rightarrow \mathrm{F}$

$4.00 \mathrm{AB}$

4.00 AB

$2.50 \mathrm{C} \rightarrow \mathrm{J}$

3.75 ABC

$3.63 \mathrm{~A} \rightarrow \mathrm{D}$

$2.88 \mathrm{~A} \rightarrow \mathrm{G}$

20

40

70
$1.13 \mathrm{JKL}$

$0.13 \mathrm{~L}$

$1.38 \mathrm{H} \rightarrow \mathrm{L}$

$2.75 \mathrm{~B} \rightarrow \mathrm{H}$

$2.13 \mathrm{E} \rightarrow \mathrm{J}$

$1.38 \mathrm{H} \rightarrow \mathrm{L}$

$2.25 \mathrm{D} \rightarrow \mathrm{J}$

$1.25 \mathrm{I} \rightarrow \mathrm{L}$

$1.50 \mathrm{G} \rightarrow \mathrm{L}$

$2.38 \mathrm{C} \rightarrow \mathrm{J}$

$2.50 \mathrm{C} \rightarrow \mathrm{J}$

$0.38 \mathrm{KL}$

$2.25 \mathrm{D} \rightarrow \mathrm{J}$

$2.75 \mathrm{~B} \rightarrow \mathrm{H}$

$2.00 \mathrm{E} \rightarrow \mathrm{J}$

$2.75 \mathrm{~B} \rightarrow \mathrm{H}$

$3.13 \mathrm{~A} \rightarrow \mathrm{F}$

$2.25 \mathrm{D} \rightarrow \mathrm{J}$

$2.28 \mathrm{D} \rightarrow \mathrm{J}$

$1.88 \mathrm{~F} \rightarrow \mathrm{J}$

$1.63 \mathrm{G} \rightarrow \mathrm{K}$

$3.38 \mathrm{~A} \rightarrow \mathrm{E}$

$3.13 \mathrm{~A} \rightarrow \mathrm{F}$

$2.88 \mathrm{~A} \rightarrow \mathrm{G}$

$2.63 \mathrm{~B} \rightarrow \mathrm{I}$

$1.50 \mathrm{G} \rightarrow \mathrm{L}$

$3.38 \mathrm{~A} \rightarrow \mathrm{E}$

\section{Experiment 2}

$\underline{\text { Mean plant stand per pot at different } P \text {. ultimum infestation levels }{ }^{\mathrm{c}}}$

Treatment $^{\mathrm{b}}$

0

20

40

70

No treatment

$\mathrm{SH}$

N4-5 extract

501R3

GL21
$4.88 \mathrm{~A}$

$5.00 \mathrm{~A}$

$3.88 \mathrm{~A} \rightarrow \mathrm{E}$

$4.63 \mathrm{AB}$

$4.88 \mathrm{~A}$

\section{(4.88 A}

$\begin{array}{lll}1.50 \mathrm{FGH} & 1.25 \mathrm{GH} & 1.25 \mathrm{GH} \\ 2.75 \mathrm{D} \rightarrow \mathrm{G} & 2.88 \mathrm{CDE} & 0.25 \mathrm{H} \\ 4.25 \mathrm{~A} \rightarrow \mathrm{D} & 3.75 \mathrm{~A} \rightarrow \mathrm{E} & 3.50 \mathrm{~A} \rightarrow \mathrm{E} \\ 1.38 \mathrm{FGH} & 0.88 \mathrm{H} & 0.25 \mathrm{H} \\ 2.88 \mathrm{C} \rightarrow \mathrm{F} & 3.88 \mathrm{~A} \rightarrow \mathrm{E} & 1.38 \mathrm{FGH}\end{array}$




$\begin{array}{lllll}\mathrm{SH}+\mathrm{N} 4-5 \text { extract } & 4.38 \mathrm{ABC} & 4.13 \mathrm{~A} \rightarrow \mathrm{E} & 4.13 \mathrm{~A} \rightarrow \mathrm{E} & 4.50 \mathrm{AB} \\ \mathrm{SH}+501 \mathrm{R} 3 & 4.63 \mathrm{AB} & 3.75 \mathrm{~A} \rightarrow \mathrm{E} & 3.75 \mathrm{~A} \rightarrow \mathrm{E} & 1.63 \mathrm{FGH} \\ \mathrm{SH}+\mathrm{GL} 21 & 5.00 \mathrm{~A} & 2.63 \mathrm{EFG} & 3.25 \mathrm{~B} \rightarrow \mathrm{E} & 1.63 \mathrm{FGH} \\ \mathrm{N} 4-5 \text { extract + GL21 } & 3.88 \mathrm{~A} \rightarrow \mathrm{E} & 4.38 \mathrm{ABC} & 4.38 \mathrm{ABC} & 3.50 \mathrm{~A} \rightarrow \mathrm{E}\end{array}$

Experiment 3

Mean plant stand per pot at different $P$. ultimum infestation levels

$\begin{array}{lllll}\text { Treatment }^{\mathrm{b}} & 0 & 20 & 40 & 70\end{array}$

\begin{tabular}{lllll}
\hline No treatment & $5.00 \mathrm{~A}$ & $0.75 \mathrm{KLM}$ & $0.88 \mathrm{KLM}$ & $0.00 \mathrm{M}$ \\
$\mathrm{SH}$ & $4.75 \mathrm{AB}$ & $1.00 \mathrm{~J} \rightarrow \mathrm{M}$ & $1.13 \mathrm{~J} \rightarrow \mathrm{M}$ & $0.00 \mathrm{M}$ \\
$\mathrm{N} 4-5$ extract & $4.25 \mathrm{~A} \rightarrow \mathrm{E}$ & $3.00 \mathrm{EFG}$ & $3.38 \mathrm{C} \rightarrow \mathrm{G}$ & $1.63 \mathrm{H} \rightarrow \mathrm{K}$ \\
$501 \mathrm{R} 3$ & $4.63 \mathrm{ABC}$ & $1.38 \mathrm{I} \rightarrow \mathrm{L}$ & $0.63 \mathrm{KLM}$ & $0.13 \mathrm{LM}$ \\
$\mathrm{GL} 21$ & $4.75 \mathrm{AB}$ & $1.13 \mathrm{~J} \rightarrow \mathrm{M}$ & $0.88 \mathrm{KLM}$ & $0.00 \mathrm{M}$ \\
$\mathrm{SH}+\mathrm{N} 4-5$ extract & $3.50 \mathrm{~B} \rightarrow \mathrm{G}$ & $3.50 \mathrm{~B} \rightarrow \mathrm{G}$ & $2.25 \mathrm{G} \rightarrow \mathrm{J}$ & $2.75 \mathrm{FGH}$ \\
$\mathrm{SH}+501 \mathrm{R} 3$ & $4.38 \mathrm{~A} \rightarrow \mathrm{D}$ & $1.25 \mathrm{~J} \rightarrow \mathrm{M}$ & $0.88 \mathrm{KLM}$ & $0.88 \mathrm{KLM}$ \\
$\mathrm{SH}+\mathrm{GL} 21$ & $5.00 \mathrm{~A}$ & $2.75 \mathrm{FGH}$ & $2.63 \mathrm{~F} \rightarrow \mathrm{I}$ & $1.50 \mathrm{H} \rightarrow \mathrm{K}$ \\
$\mathrm{N} 4-5$ extract + GL21 & $3.88 \mathrm{~A} \rightarrow \mathrm{F}$ & $2.63 \mathrm{~F} \rightarrow \mathrm{I}$ & $3.25 \mathrm{D} \rightarrow \mathrm{G}$ & $2.75 \mathrm{FGH}$ \\
\hline
\end{tabular}

${ }^{a}$ Values are the mean of one experiment expressed as mean plant stand per pot. Results from experiments were not combined prior to analysis as there was a significant experiment $\times$ treatment interaction $(P=0.0006)$. Treatments in all three experiments contained eight replicate pots, each containing five seeds. Numbers followed by the same letter are not significantly different $(P \leq 0.05)$ as determined by least significant difference. Least significant difference in experiments 1,2 , and 3 was $1.4936,1.6062$, and 1.3633, respectively.

${ }^{b}$ No treatment indicates that cucumber seeds were not treated prior to being sown and there were no cover crop or in-furrow applications. SH, sunn hemp incorporated into the potting mix; N4-5 extract, ethanol extract of $S$. marcescens N4-5; 501R3, E. cloacae 501R3 applied as a seed treatment; GL21, T. virens GL21 applied in furrow as a drench.

${ }^{\mathrm{c}}$ Quantity of sporangia of $P$. ultimum per $\mathrm{cm}^{3}$ of potting mix inoculum. 


\section{Table 4}

Suppression of damping-off of cucumber caused by Pythium ultimum with various treatments containing sorghumsudangrass, sunn hemp, ethanol extract of Serratia marcescens N4-5, or Trichoderma virens GL21 in soil \#2 ${ }^{\mathrm{a}}$.

$\underline{\text { Mean plant stand per pot at different } P \text {. ultimum infestation levels }}{ }^{\mathrm{c}}$

Treatment ${ }^{\mathrm{b}}$

No treatment

Thiram

SSG

$\mathrm{SH}$

N4-5 extract

GL21

N4-5 extract + GL21

N4-5 extract + SSG

$\mathrm{N} 4-5$ extract $+\mathrm{SH}$

$\mathrm{N} 4-5$ extract $+\mathrm{SSG}+\mathrm{GL} 21$
0

$4.94 \mathrm{AB}$

$4.75 \mathrm{~A} \rightarrow \mathrm{D}$

$4.88 \mathrm{AB}$

$5.00 \mathrm{~A}$

4.75 A $\rightarrow \mathrm{D}$

4.69 $\mathrm{A} \rightarrow \mathrm{D}$

4.69 A $\rightarrow \mathrm{D}$

$4.75 \mathrm{~A} \rightarrow \mathrm{D}$

$4.75 \mathrm{~A} \rightarrow \mathrm{D}$

$4.69 \mathrm{~A} \rightarrow \mathrm{D}$
20

1.94 LMN

$4.50 \mathrm{~A} \rightarrow \mathrm{F}$

$2.38 \mathrm{~J} \rightarrow \mathrm{M}$

$3.56 \mathrm{E} \rightarrow \mathrm{I}$

$3.94 \mathrm{C} \rightarrow \mathrm{G}$

$4.88 \mathrm{AB}$

$4.81 \mathrm{~A} \rightarrow \mathrm{C}$

$4.13 \mathrm{~A} \rightarrow \mathrm{G}$

$3.81 \mathrm{C} \rightarrow \mathrm{G}$

$4.69 A \rightarrow D$
80

${ }^{\mathrm{a}}$ Values are the mean of two experiments $(\mathrm{n}=2)$ expressed as mean plant stand per pot. Results from experiments were combined prior to analysis as there was no significant experiment $\times$ treatment interaction $(P=0.6791)$.

Treatments from both experiments contained eight replicate pots, each containing five seeds. Numbers followed by the same letter are not significantly different $(P \leq 0.05)$ as determined least significant difference. Least significant difference was 1.0085 .

${ }^{\mathrm{b}}$ No treatment indicates that cucumber seeds were not treated prior to being sown and there were no cover crop or in-furrow applications. SSG, sorghum-sudangrass incorporated into the soil; SH, sunn hemp incorporated into the soil; N4-5 extract, ethanol extract of S. marcescens N4-5 applied as a seed treatment; GL21, T. virens GL21 applied in furrow to the seed area as a drench. In-furrow application delivered approximately $10^{7}$ Trichoderma-like CFU to the seed region. 
${ }^{c}$ Quantity of sporangia of P. ultimum per $\mathrm{cm}^{3}$ of inoculum. Inoculum was applied in soil \#2 (sandy loam, 3.0\% organic matter, $\mathrm{pH} 4.5$ ) using an inoculum sandwich technique where treatments and seed were sandwiched between layers of natural soil \#2 containing sporangia of $P$. ultimum which were, in turn, on top of a layer of potting mix. 
Table 5

Suppression of damping-off of cucumber caused by Pythium ultimum with various treatments containing sorghumsudangrass, sunn hemp, ethanol extract of Serratia marcescens N4-5, or Trichoderma virens GL21 in soil \#13 ${ }^{\mathrm{a}}$.

Experiment 1

$\underline{\text { Mean plant stand per pot at different } P . \text { ultimum infestation levels }}{ }^{\mathrm{c}}$

Treatment $^{\mathrm{b}}$

0

20

50

80

\begin{tabular}{|c|c|c|c|c|}
\hline No treatment & $5.00 \mathrm{~A}$ & $1.38 \mathrm{H} \rightarrow \mathrm{K}$ & $0 \mathrm{~L}$ & $0 \mathrm{~L}$ \\
\hline Thiram & $4.88 \mathrm{AB}$ & $4.38 \mathrm{~A} \rightarrow \mathrm{D}$ & $4.00 \mathrm{~A} \rightarrow \mathrm{D}$ & $4.00 \mathrm{~A} \rightarrow \mathrm{D}$ \\
\hline SSG & $5.00 \mathrm{~A}$ & $2.38 \mathrm{GHI}$ & $0.63 \mathrm{JKL}$ & $2.50 \mathrm{FGH}$ \\
\hline SH & $5.00 \mathrm{~A}$ & $1.63 \mathrm{HIJ}$ & $0.25 \mathrm{KL}$ & $1.13 \mathrm{I} \rightarrow \mathrm{L}$ \\
\hline N4-5 extract & $4.63 \mathrm{~A} \rightarrow \mathrm{D}$ & $3.38 \mathrm{D} \rightarrow \mathrm{G}$ & $3.50 \mathrm{C} \rightarrow \mathrm{G}$ & $2.63 \mathrm{E} \rightarrow \mathrm{H}$ \\
\hline GL21 & $5.00 \mathrm{~A}$ & $2.63 \mathrm{E} \rightarrow \mathrm{H}$ & $0.75 \mathrm{JKL}$ & $1.13 \mathrm{I} \rightarrow \mathrm{L}$ \\
\hline N4-5 extract + GL21 & $4.63 \mathrm{~A} \rightarrow \mathrm{D}$ & $4.75 \mathrm{ABC}$ & $3.50 \mathrm{C} \rightarrow \mathrm{G}$ & $3.63 \mathrm{~B} \rightarrow \mathrm{G}$ \\
\hline $\mathrm{N} 4-5$ extract + SSG & $4.88 \mathrm{AB}$ & $3.75 \mathrm{~A} \rightarrow \mathrm{F}$ & $3.75 \mathrm{~A} \rightarrow \mathrm{F}$ & $3.50 \mathrm{C} \rightarrow \mathrm{G}$ \\
\hline $\mathrm{N} 4-5$ extract $+\mathrm{SH}$ & $4.88 \mathrm{AB}$ & $3.88 \mathrm{~A} \rightarrow \mathrm{E}$ & $3.63 \mathrm{~B} \rightarrow \mathrm{G}$ & $5.00 \mathrm{~A}$ \\
\hline $\mathrm{N} 4-5$ extract $+\mathrm{SSG}+\mathrm{GL} 21$ & $5.00 \mathrm{~A}$ & $4.63 \mathrm{~A} \rightarrow \mathrm{D}$ & $4.25 \mathrm{~A} \rightarrow \mathrm{D}$ & $4.63 \mathrm{~A} \rightarrow \mathrm{D}$ \\
\hline
\end{tabular}

Experiment 2

$\underline{\text { Mean plant stand per pot at different } P \text {. ultimum infestation levels }}{ }^{\mathrm{c}}$

Treatment $^{\mathrm{b}}$

0

20

50

80

$\begin{array}{lllll}\text { No treatment } & 4.75 \mathrm{ABC} & 0.75 \mathrm{H} & 1.50 \mathrm{GH} & 1.00 \mathrm{H} \\ \text { Thiram } & 4.63 \mathrm{ABC} & 4.88 \mathrm{AB} & 3.88 \mathrm{~A} \rightarrow \mathrm{E} & 4.88 \mathrm{AB} \\ \text { SSG } & \mathrm{ND} & \mathrm{ND} & 1.63 \mathrm{GH} & 0.75 \mathrm{H} \\ \text { SH } & 4.88 \mathrm{AB} & 3.00 \mathrm{EF} & \mathrm{ND} & 1.00 \mathrm{H} \\ \text { N4-5 extract } & 4.88 \mathrm{AB} & 4.63 \mathrm{ABC} & 3.75 \mathrm{~B} \rightarrow \mathrm{E} & 3.88 \mathrm{~A} \rightarrow \mathrm{E}\end{array}$


GL21

N4-5 extract + GL21

N4-5 extract + SSG

N4-5 extract + SH

N4-5 extract + SSG + GL21
$4.88 \mathrm{AB}$

4.38 ABC

ND

$4.88 \mathrm{AB}$

ND
$4.25 \mathrm{~A} \rightarrow \mathrm{D}$

$4.88 \mathrm{AB}$

ND

4.38 ABC

ND
ND

$5.00 \mathrm{~A}$

$3.00 \mathrm{EF}$

ND

4.38 $\mathrm{ABC}$
$2.23 \mathrm{FG}$

$3.88 \mathrm{~A} \rightarrow \mathrm{E}$

$3.75 \mathrm{~B} \rightarrow \mathrm{E}$

3.63 CDE

3.13 DEF

${ }^{a}$ Values are the mean of one experiment expressed as mean plant stand per pot. Results from experiments were not combined prior to analysis as there was a significant experiment $\times$ treatment interaction $(P=0.0052)$. Treatments in both experiments contained eight replicate pots, each containing five seeds. Numbers followed by the same letter are not significantly different $(P \leq 0.05)$ as determined by least significant difference. Least significant difference in experiments 1 and 2 was 1.3624 and 1.1916 , respectively.

${ }^{b}$ No treatment indicates that cucumber seeds were not treated prior to being sown and there were no cover crop or in-furrow applications. SSG, sorghum-sudangrass incorporated into the soil; $\mathrm{SH}$, sunn hemp incorporated into the soil ; N4-5 extract, ethanol extract of S. marcescens N4-5 applied as a seed treatment; GL21, T. virens GL21 applied in furrow to the seed area as a drench. In-furrow application delivered approximately $10^{7}$ Trichoderma-like CFU to the seed region.

${ }^{\mathrm{c}}$ Quantity of sporangia of P. ultimum per $\mathrm{cm}^{3}$ of inoculum. Inoculum was applied in soil \#13 (sand, 2.3\% organic matter, $\mathrm{pH}$ 4.7) using an inoculum sandwich technique where treatments and seed were sandwiched between layers of natural soil \#13 containing sporangia of $P$. ultimum which were, in turn, on top of a layer of potting mix. 
Table 6

Suppression of damping-off of cucumber caused by Pythium ultimum with various treatments containing sorghumsudangrass, sunn hemp, ethanol extract of Serratia marcescens N4-5, or Trichoderma virens GL21 in soil \#15 ${ }^{\mathrm{a}}$.

Experiment 1

$\underline{\text { Mean plant stand per pot at different } P \text {. ultimum infestation levels }{ }^{\mathrm{c}}}$

Treatment $^{\mathrm{b}}$

0

20

50

80

\begin{tabular}{lllll}
\hline No treatment & $3.75 \mathrm{~A} \rightarrow \mathrm{E}$ & $0.38 \mathrm{KL}$ & $0.25 \mathrm{KL}$ & $0.00 \mathrm{~L}$ \\
Thiram & $4.75 \mathrm{~A}$ & $2.75 \mathrm{C} \rightarrow \mathrm{H}$ & $2.63 \mathrm{D} \rightarrow \mathrm{H}$ & $3.25 \mathrm{~A} \rightarrow \mathrm{G}$ \\
SSG & $4.13 \mathrm{~A} \rightarrow \mathrm{D}$ & $0.00 \mathrm{~L}$ & $0.13 \mathrm{~L}$ & $0.00 \mathrm{~L}$ \\
SH & $3.63 \mathrm{~A} \rightarrow \mathrm{F}$ & $0.63 \mathrm{JKL}$ & $0.00 \mathrm{~L}$ & $0.00 \mathrm{~L}$ \\
$\mathrm{~N} 4-5$ extract & $3.50 \mathrm{~A} \rightarrow \mathrm{F}$ & $2.88 \mathrm{C} \rightarrow \mathrm{H}$ & $2.75 \mathrm{C} \rightarrow \mathrm{H}$ & $1.75 \mathrm{G} \rightarrow \mathrm{K}$ \\
GL21 & $3.88 \mathrm{~A} \rightarrow \mathrm{E}$ & $0.75 \mathrm{JKL}$ & $0.75 \mathrm{JKL}$ & $0.25 \mathrm{KL}$ \\
$\mathrm{N} 4-5$ extract + GL21 & $4.50 \mathrm{AB}$ & $2.38 \mathrm{E} \rightarrow \mathrm{I}$ & $3.50 \mathrm{~A} \rightarrow \mathrm{F}$ & $2.88 \mathrm{C} \rightarrow \mathrm{H}$ \\
$\mathrm{N} 4-5$ extract $+\mathrm{SSG}$ & $4.00 \mathrm{~A} \rightarrow \mathrm{D}$ & $1.38 \mathrm{H} \rightarrow \mathrm{L}$ & $2.13 \mathrm{~F} \rightarrow \mathrm{I}$ & $1.00 \mathrm{I} \rightarrow \mathrm{L}$ \\
$\mathrm{N} 4-5$ extract $+\mathrm{SH}$ & $3.63 \mathrm{~A} \rightarrow \mathrm{F}$ & $2.63 \mathrm{D} \rightarrow \mathrm{H}$ & $2.63 \mathrm{D} \rightarrow \mathrm{H}$ & $2.88 \mathrm{C} \rightarrow \mathrm{H}$ \\
$\mathrm{N} 4-5$ extract $+\mathrm{SSG}+\mathrm{GL} 21$ & $4.25 \mathrm{ABC}$ & $4.63 \mathrm{AB}$ & $3.13 \mathrm{~B} \rightarrow \mathrm{G}$ & $2.38 \mathrm{E} \rightarrow \mathrm{I}$
\end{tabular}

Experiment 2

$\underline{\text { Mean plant stand per pot at different } P \text {. ultimum infestation levels }}{ }^{\mathrm{c}}$

Treatment $^{\mathrm{b}}$

0

20

50

80

$\begin{array}{lcccc}\text { No treatment } & 4.38 \mathrm{~A} \rightarrow \mathrm{D} & 1.25 \mathrm{~J} \rightarrow \mathrm{N} & 0.88 \mathrm{~K} \rightarrow \mathrm{N} & 0.38 \mathrm{~N} \\ \text { Thiram } & 4.88 \mathrm{AB} & 3.25 \mathrm{D} \rightarrow \mathrm{H} & 3.63 \mathrm{~A} \rightarrow \mathrm{F} & 0.38 \mathrm{~N} \\ \text { SSG } & 3.50 \mathrm{~B} \rightarrow \mathrm{F} & 0.63 \mathrm{LMN} & 0.88 \mathrm{~K} \rightarrow \mathrm{N} & 0.33 \mathrm{~N} \\ \text { SH } & 2.25 \mathrm{~F} \rightarrow \mathrm{K} & 0.75 \mathrm{LMN} & 0.50 \mathrm{MN} & 0.50 \mathrm{MN} \\ \text { N4-5 extract } & 3.25 \mathrm{D} \rightarrow \mathrm{H} & 2.25 \mathrm{~F} \rightarrow \mathrm{K} & 4.25 \mathrm{~A} \rightarrow \mathrm{D} & 1.13 \mathrm{~J} \rightarrow \mathrm{N}\end{array}$


GL21

N4-5 extract + GL21

N4-5 extract + SSG

$\mathrm{N} 4-5$ extract $+\mathrm{SH}$

N4-5 extract + SSG + GL21
$4.00 \mathrm{~A} \rightarrow \mathrm{D}$

$5.00 \mathrm{~A}$

$4.88 \mathrm{AB}$

$3.75 \mathrm{~A} \rightarrow \mathrm{E}$

$4.88 \mathrm{AB}$
$3.50 \mathrm{~B} \rightarrow \mathrm{F}$

$3.25 \mathrm{D} \rightarrow \mathrm{H}$

4.75 ABC

$2.38 \mathrm{E} \rightarrow \mathrm{J}$

$3.75 \mathrm{~A} \rightarrow \mathrm{E}$
$2.38 \mathrm{E} \rightarrow \mathrm{J}$

$4.13 \mathrm{~A} \rightarrow \mathrm{D}$

$2.00 \mathrm{G} \rightarrow \mathrm{L}$

$3.38 \mathrm{C} \rightarrow \mathrm{G}$

$3.63 \mathrm{~A} \rightarrow \mathrm{F}$
$1.88 \mathrm{H} \rightarrow \mathrm{M}$

$2.25 \mathrm{~F} \rightarrow \mathrm{K}$

$3.00 \mathrm{D} \rightarrow \mathrm{I}$

$1.63 \mathrm{I} \rightarrow \mathrm{N}$

$4.00 \mathrm{~A} \rightarrow \mathrm{D}$

${ }^{a}$ Values are the mean of one experiment expressed as mean plant stand per pot. Results from experiments were not combined prior to analysis as there was a significant experiment $\times$ treatment interaction $(P<0.0001)$. Treatments in both experiments contained eight replicate pots, each containing five seeds. Numbers followed by the same letter are not significantly different $(P \leq 0.05)$ as determined by least significant difference. Least significant difference in experiments 1 and 2 was 1.5041 and 1.4215 , respectively.

${ }^{b}$ No treatment indicates that cucumber seeds were not treated prior to being sown and there were no cover crop or in-furrow applications. SSG, sorghum-sudangrass incorporated into the soil; SH, sunn hemp incorporated into the soil; N4-5 extract, ethanol extract of S. marcescens N4-5 applied as a seed treatment; GL21, T. virens GL21 applied in furrow to the seed area as a drench. In-furrow application delivered approximately $10^{7}$ Trichoderma-like CFU to the seed region.

${ }^{\mathrm{c}}$ Quantity of sporangia of P. ultimum per $\mathrm{cm}^{3}$ of inoculum. Inoculum was applied in soil \#15 (loam, 1.4\% organic matter, pH 5.1) using an inoculum sandwich technique where treatments and seed were sandwiched between layers of natural soil \#15 containing sporangia of $P$. ultimum which were, in turn, on top of a layer of potting mix. 
Fig. 1. Soil microbial community composition determined by phospholipid fatty acid analysis of four different soils and these soils amended with sorghum-sudangrass or sunn hemp cover crops. Natural soils were \#2 (sandy loam, 106 ppm available P, 48 ppm K, 50 ppm Mg, 250 ppm Ca, 3.1 CEC, 3.0\% organic matter, pH 4.5), \#11 (Ultisol, sandy loam, 108 ppm available P, 141 ppm K, 60 ppm Mg, 620 ppm Ca, 6.3 CEC, 4.8\% organic matter, pH 5.1), \#13 (sand, 12 ppm available P, 40 ppm K, 65 ppm Mg, 240 ppm Ca, 4.0 CEC, 2.3\% organic matter, pH 4.7), \#15 (loam, 41 ppm available P, 134 ppm K, 105 ppm Mg, 480 ppm Ca, 5.8 CEC, 1.4\% organic matter, pH 5.1), and \#18 (sandy loam, 32 ppm available P, 31 ppm K, 45 ppm Mg, 170 ppm Ca, 3.1 CEC, $2.7 \%$ organic matter, $\mathrm{pH} 4.6$ ). Cover crops were incorporated into natural soils at a rate of $0.5 \%(w / w)$, or no cover crop was added. Community composition was determined after 14 days incubation at $22^{\circ} \mathrm{C}$ in a growth chamber in the presence of cucumber. Results are from a single experiment. Soil \#11 was included in this analysis, but studied elsewhere (Roberts et al., 2016). Closed symbols represent non-amended soils while open symbols represent soils amended with dried, ground cover crop residue. 
Soil 2

- Soil 11

- Soil 13

- Soil 15

- Soil 18

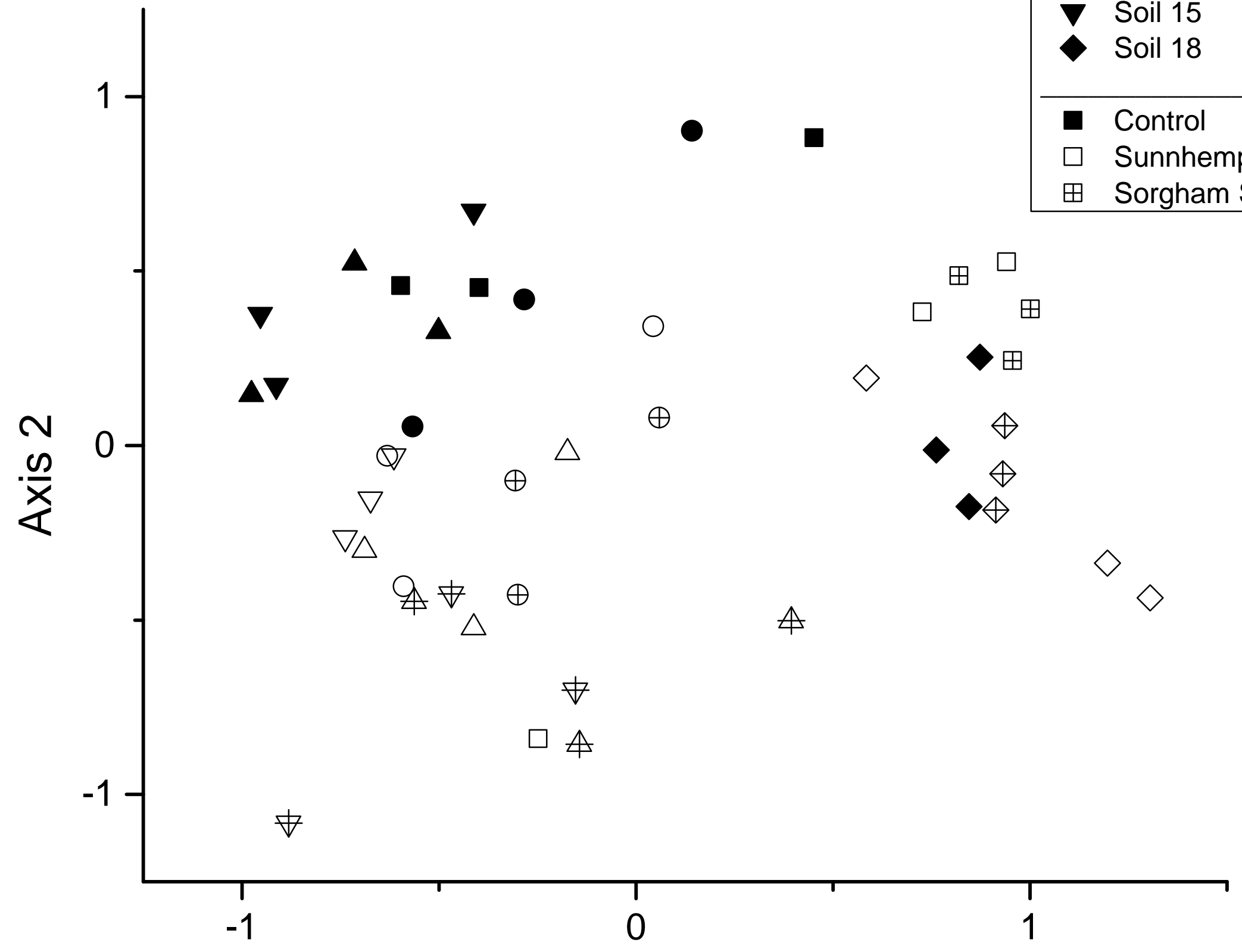

Axis 1 